\title{
Nabywanie działek gruntu wchodzących w skład gospodarstwa rolnego przekazanego państwu na podstawie przepisów emerytalno-rentowych
}

1. W latach 70. i 80. XX wieku jednym z warunków uzyskania świadczenia emerytalnego przez rolnika było przekazanie gospodarstwa rolnego następcy lub państwu. Ponieważ gospodarstwo rolne było nie tylko miejscem pracy, ale także miejscem zamieszkania rolnika i jego rodziny, ustawodawca zezwolił na zatrzymanie przez rolnika budynków lub bezpłatne korzystanie z lokalu mieszkalnego, pomieszczeń gospodarskich i ogrodów przydomowych. Konsekwencje własnościowe takich decyzji są widoczne do dziś.

Możliwość zachowania własności budynków mieszkalnych, a nawet wszystkich budynków wzniesionych wokół wspólnego podwórza (siedlisko), nie zmieniała faktu, że własność gruntu pod tymi budynkami przechodziła na rzecz państwa w zamian za świadczenie emerytalno-rentowe dla rolnika. Taka konstrukcja prawna stanowiła odejście od zasady superficies solo cedit, właściwej dla pojęcia nieruchomości gruntowej, ale w pewnej mierze rozwiązywała problem mieszkaniowy na wsi.

Stan prawny dotyczący oddzielenia własności budynków od własności gruntu nie był prawidłowy i wymagał interwencji ustawodawcy. Stosowanie przepisów w opisanym zakresie jest utrudnione ze względu na liczne problemy interpretacyjne. Podstawowym problemem stała się skuteczna realizacja roszczeń o nabycie gruntu pod budynkami.

Celem niniejszego opracowania jest rozstrzygnięcie problemów związanych z dochodzeniem roszczeń o nabycie gruntu pod budynkami wcho- 
dzącymi niegdyś w skład gospodarstwa rolnego. Należy sprawdzić, czy analizowane przepisy odpowiadają aktualnym potrzebom oraz jaka jest korelacja regulacji uwłaszczeniowych dotyczących tej grupy rolników, którzy otrzymali zaopatrzenie emerytalno-rentowe w zamian za przekazanie gospodarstwa rolnego państwu, z uwłaszczeniem innych podmiotów. Problematyka ta ma wymiar praktyczny, ponieważ w sprawach roszczeń zgłaszanych przez rolników bądź ich zstępnych nie wypracowano jednolitej linii orzeczniczej. Przedstawione rozważania prowadzić będą do sformułowania wniosków de lege ferenda $\mathrm{w}$ zakresie, w jakim istniejące rozwiązania prawne wymagają korekty.

2. Zgodnie z art. 6 ustawy z 24 lutego 1989 r. o zmianie ustawy o ubezpieczeniu społecznym rolników indywidualnych i członków ich rodzin oraz o zmianie ustawy o podatku rolnym ${ }^{1}$ właścicielom budynków znajdujących się na działce gruntu, która wchodziła w skład gospodarstwa rolnego przekazanego państwu na podstawie przepisów obowiązujących przed 1 stycznia 1983 r., przysługuje nieodpłatnie na własność działka gruntu, na której te budynki zostały wzniesione. Z własnością wyłączonej nieruchomości jest związana służebność gruntowa w zakresie niezbędnym do korzystania z niej. O przeniesieniu własności działki, jej wielkości oraz o ustanowieniu służebności orzeka terenowy organ administracji państwowej o właściwości szczególnej stopnia podstawowego.

Aby właściwie zrozumieć cel przywołanej regulacji, należy najpierw zbadać jej kontekst historyczny. Rozstrzygająca jest okoliczność, że art. 6 u.z.u.s.r. odnosi się tylko do działek gruntu, które wchodziły w skład gospodarstwa rolnego przekazanego państwu na podstawie przepisów obowiązujących przed 1 stycznia $1983 \mathrm{r}$. Zatem w takich odległych przepisach należy poszukiwać norm prawnych, które umożliwiały w chwili przekazania gospodarstwa rolnego państwu zachowanie przez rolnika odrębnej własności budynku mieszkalnego, a także innych budynków.

Rozdzielenie własności budynku od własności gruntu pod budynkiem stało się możliwe na podstawie ustawy z 24 stycznia 1968 r. o rentach i innych świadczeniach dla rolników przekazujących nieruchomości rolne na własność państwa ${ }^{2}$. Rolnik mógł zatrzymać na własność budynki wchodzące w skład przekazanych państwu nieruchomości. W tym przypadku budynki stanowiły odrębny od gruntu przedmiot własności (art. 4 ust. 1 ustawy). Ustawa z 24 stycznia 1968 r. wprowadziła wyjątek od zasady superficies

\footnotetext{
${ }^{1}$ Dz. U. Nr 10, poz. 53 ze zm. [dalej: u.z.u.s.r.].

${ }^{2}$ Dz. U. Nr 3, poz. 15 ze zm.
} 
solo cedit, sformułowanej w art. $46 \S 1$ k.c. Zgodnie z art. 48 k.c. do części składowych gruntu należą w szczególności budynki i inne urządzenia trwale związane z gruntem. Omawiana ustawa z 1968 r. nie przewidywała możliwości uzyskania przez rolnika własności działki pod budynkami stanowiącymi odrębny przedmiot własności.

To szczególne rozwiązanie prawne zostało powtórzone w kolejnych ustawach regulujących renty i świadczenia emerytalne dla rolników. Zgodnie z art. 11 ust. 1 ustawy z 29 maja 1974 r. o przekazywaniu gospodarstw rolnych na własność państwa za rentę i spłaty pieniężne ${ }^{3}$ rolnik, który przekazał gospodarstwo rolne za rentę, mógł zatrzymać budynki wchodzące w skład nieruchomości przekazywanych państwu. Budynki takie stawały się odrębnym od gruntu przedmiotem własności z chwilą przejęcia nieruchomości przez państwo. Taki stan rzeczy był traktowany jako przejściowy, gdyż docelowo własność budynków miała przypaść państwu (art. 11 ust. 2 i 3 ustawy).

Kolejna była ustawa z 27 października 1977 r. o zaopatrzeniu emerytalnym oraz innych świadczeniach dla rolników i ich rodzin ${ }^{4}$. Ustawa ta, zachowując zasadę, że wyłączone z przejętego gospodarstwa rolnego i zatrzymane przez rolnika budynki stanowią odrębny przedmiot własności (art. 51 ust. 1), nie zawierała już jednak przepisu o przejściu nieruchomości budynkowych po śmierci rolnika na własność państwa. Dlatego w orzecznictwie sądowym sformułowano zasadę, że jeśli własność budynków zatrzymanych przez rolnika nie wygasła przed 1 stycznia 1978 r., to z dniem wejścia w życie ustawy z 27 października 1977 r. stała się prawem dziedzicznym 5 .

Dopiero ustawa z 14 grudnia 1982 r. o ubezpieczeniu społecznym rolników indywidualnych i członków ich rodzin ${ }^{6}$ powróciła do zasady superficies solo cedit, stanowiąc $\mathrm{w}$ art. 57 ust. 1, że z gospodarstwa rolnego przekazanego państwu rolnik może wyłączyć i zachować własność działki gruntu, na której wzniesione są budynki. Z własnością wyłączonej nieruchomości związana była służebność gruntowa w zakresie niezbędnym do korzystania z tej nieruchomości.

Oznaczało to, że rolnik był właścicielem działki zabudowanej i było to prawo dziedziczne oraz zbywalne. Rezultatem wejścia w życie $\mathrm{z}$ dniem 1 stycznia 1983 r. ustawy z 14 grudnia 1982 r. było zróżnicowanie sytuacji prawnej rolników w zależności od tego, w jakim czasie wydano decyzję o przejęciu gospodarstwa rolnego na rzecz państwa. Jeżeli miało to miej-

${ }^{3}$ Dz. U. Nr 21, poz. 118 ze zm.

${ }^{4}$ Dz. U. Nr 32, poz. 140 ze zm.

5 Wyrok SN z 25 czerwca 1997 r., sygn. akt: II CKU 63/97, OSNC 1997, nr 12, poz. 208.

${ }^{6}$ Tekst jedn. Dz. U. z 1989 r., Nr 24, poz. 133 ze zm. 
sce przed 1 stycznia 1983 r., to rolnicy mogli zachować jedynie własność budynków, a jeżeli po tej dacie - własność działki siedliskowej wraz ze wzniesionymi na niej budynkami.

Ustawodawca uznał, że należy naprawić skutki regulacji obowiązujących od 27 stycznia 1968 r. do 1 stycznia 1983 r. i przyznać właścicielom budynków stosowne roszczenia do działek, na których posadowiono budynki. Ta myśl legislacyjna znalazła wyraz w art. 6 u.z.u.s.r., zgodnie z którym właścicielom budynków znajdujących się na działce gruntu, która wchodziła w skład gospodarstwa rolnego przekazanego państwu przed 1 stycznia 1983 r., przysługuje nieodpłatnie na własność działka gruntu, na której te budynki wzniesiono. Z uwagi na to, że własność budynków od 1 stycznia 1978 r. była uznawana za prawo dziedziczne, powyższe uprawnienia odnosiły się zarówno do rolników, którzy przekazali gospodarstwo rolne państwu, jak i do ich następców prawnych, będących właścicielami budynków? ${ }^{7}$.

Omawiana regulacja zamieszczona w art. 6 u.z.u.s.r. odnosi się do przypadków, gdy budynek stanowi odrębny od gruntu przedmiot własności. Właścicielem gruntu, na którym posadowiono budynek, jest państwo (Skarb Państwa). Natomiast odrębna własność budynku przysługuje innej osobie. Na ogół będzie to emerytowany rolnik bądź jego spadkobiercy. Niemniej taka nieruchomość budynkowa mogła zostać później zbyta w drodze sprzedaży, darowizny lub wniesiona aportem do spółki. Nowy właściciel budynków nie musiał być członkiem rodziny rolnika.

Roszczenie z art. 6 u.z.u.s.r. przysługuje zatem każdemu właścicielowi budynków, bez względu na to, kiedy i jak je nabył, o ile budynki te znajdują się na działce wchodzącej w skład gospodarstwa rolnego przekazanego państwu. Jak podkreślono w orzecznictwie sądowym, o uzyskanie wskazanej w omawianym przepisie własności działki mogą ubiegać się osoby, które nie tylko nie są osobami przekazującymi gospodarstwo rolne, ale nawet ich spadkobiercami ${ }^{8}$. Również w piśmiennictwie formułowany był pogląd, że analizowane uprawnienie przysługuje każdemu podmiotowi, który potrafi wykazać, że przysługuje mu prawo własności do budynków, bez względu na sposób jego nabycia. Nie można zatem pojęcia następstwa prawnego zawężać jedynie do sukcesji uniwersalnej.

7 Wyrok NSA z 13 marca 1990 r., sygn. akt: II SA 77/90, Lex nr 36677.

${ }^{8}$ Wyrok WSA w Lublinie z 25 października 2011 r., sygn. akt: II SA/Lu 589/11, Lex nr 1094758; wyrok NSA z 1 grudnia 2010 r., sygn. akt: I OSK 1648/10, Lex nr 745116.

${ }^{9}$ E. Klat-Górska, Nabycie prawa własności nieruchomości budynkowej przez nastęcę rolnika, „Nowe Zeszyty Samorządowe. Opinie Prawne” 2010, nr 5, poz. 80. 
Niemniej stanowisko judykatury w omawianej kwestii nie jest jednolite. Istnieje pogląd, że unormowanie art. 6 u.z.u.s.r. odnosi się do rolników, którzy przekazali gospodarstwo rolne państwu na podstawie przepisów obowiązujących przed 1 stycznia 1983 r., jak i do ich następców prawnych - tylko i wyłącznie do tych podmiotów ${ }^{10}$. Omawiany przepis był pomyślany jako podstawa rekompensaty dla rolników przekazujących państwu gospodarstwo rolne przed 1 stycznia 1983 r. bez możliwości zachowania działki siedliskowej. Rekompensata miałaby być przeznaczona tylko dla rolników i ich następców prawnych będących członkami rodziny.

Zaprezentowane stanowisko nie znajduje uzasadnienia $\mathrm{w}$ treści art. 6 u.z.u.s.r. Wprowadzając powyższe unormowanie, ustawodawca nie odwołał się do funkcji socjalnej przepisów, które przed 1 stycznia $1983 \mathrm{r}$. gwarantowały rolnikom i ich rodzinom zachowanie miejsca zamieszkania po przekazaniu gospodarstwa rolnego państwu. Omawiany art. 6 u.z.u.s.r. stanowi konsekwencję powrotu do zasady superficies solo cedit w sytuacji, gdy rolnik korzystał z przyznanego uprawnienia i postanawiał wyłączyć i zachować własność budynków wzniesionych na działce gruntu wchodzącego w skład przekazywanego państwu gospodarstwa rolnego.

Ustawodawca, wprowadzając to unormowanie, dążył do poprawy ładu przestrzennego, którego wyznacznikami są w szczególności prawo własności, walory ekonomiczne przestrzeni i potrzeby interesu publicznego. Należyte ukształtowanie prawa własności wymagało przywrócenia zasady superficies solo cedit i zapewnienia wydzielonym działkom siedliskowym odpowiedniej obsługi komunikacyjnej z uwzględnieniem właściwego dostępu do drogi publicznej. Powyższe rozwiązanie powinno objąć każdoczesnego właściciela budynków wyłączonych z przekazanego państwu gospodarstwa rolnego. Dla stosowania art. 6 u.z.u.s.r. nie ma znaczenia, kto aktualnie jest właścicielem budynków, a zwłaszcza kiedy i jak je nabył, o ile budynki te znajdują się na działce wchodzącej w skład gospodarstwa rolnego przekazanego państwu przed 1 stycznia $1983 \mathrm{r}$.

Uprawnienie $\mathrm{z}$ art. 6 u.z.u.s.r. przysługuje tylko właścicielom budynków znajdujących się na działce gruntu, która wchodziła w skład gospodarstwa rolnego przekazanego państwu. Nie ma podstaw, aby kwestionować tak jednoznacznie określony zakres podmiotowy regulacji. Dlatego nie można przyjąć tezy, że pierwszeństwo przed właścicielem budynku ma osoba trzecia, która własnym nakładem wzniosła ów budynek na gruncie osoby bliskiej będącej właścicielem gospodarstwa rolnego przekazanego państwu przed 1 stycznia 1983 r. w zamian za zaopatrzenie emerytalno-rentowe.

${ }^{10}$ Wyrok WSA w Olsztynie z 6 maja 2009 r., sygn. akt: II SA/O1 136/09, Lex nr 557060. 
Okoliczność, że osoba trzecia poniosła nakłady na budowę budynków, które następnie właściciel gospodarstwa rolnego zachował w odrębnej własności po przekazaniu gruntów państwu, nie ma doniosłości prawnej na tle art. 6 u.z.u.s.r. ${ }^{11}$

Kolejny problem wynika z faktu, że unormowanie z art. 6 u.z.u.s.r. weszło w życie w czasie, gdy właścicielem przejętych gruntów było tylko państwo. Przepis ten nie uwzględnia późniejszych procesów komunalizacyjnych.

Trzeba jednak przyjąć, że roszczenie o nieodpłatne nabycie własności działki pod budynkiem stanowiącym odrębny od gruntu przedmiot własności może być realizowane zarówno wtedy, gdy Skarb Państwa nadal jest właścicielem gruntu pod budynkiem, jak i wtedy, gdy w drodze komunalizacji własność tego gruntu przeszła na gminę ${ }^{12}$. Wobec tego omawiany art. 6 u.z.u.s.r. ma zastosowanie także w stosunku do nieruchomości, co do której gmina nabyła prawo własności na podstawie art. 5 ust. 1 pkt 1 ustawy z 10 maja 1990 r. - Przepisy wprowadzające ustawę o samorządzie terytorialnym i ustawę o pracownikach samorządowych ${ }^{13}$. W związku z utworzeniem od 1 stycznia 1999 r. kolejnych jednostek samorządu terytorialnego, czyli powiatów i samorządów wojewódzkich, należy uznać, że unormowanie $\mathrm{z}$ art. 6 u.z.u.s.r. może być stosowane także wobec gruntów przekazanych przez Skarb Państwa na własność powiatu lub samorządu województwa.

Wykluczyć natomiast należy dochodzenie roszczenia, o którym mowa $\mathrm{w}$ art. 6 u.z.u.s.r., w przypadku sprzedaży przed datą wejścia w życie komentowanej ustawy, tj. przed 28 lutego 1989 r., gruntu pod budynkiem na rzecz osoby trzeciej. Wobec tego właściciele zachowanych na odrębną własność budynków, znajdujących się w chwili wejścia w życie ustawy z 24 lutego 1989 r. na gruncie stanowiącym własność podmiotu prywatnego, nie mogą żądać od właściwego organu administracji publicznej wydania decyzji o nieodpłatnym przeniesieniu na nich własności tego gruntu ${ }^{14}$. Skoro przeniesienie własności działki pod budynkiem na rzecz właściciela budynku następuje w drodze decyzji administracyjnej wydawanej przez organ administracji publicznej, to nie sposób uznać, aby chodziło o uszczuplenie majątku prywatnego. Decyzja administracyjna, jako rozstrzygnięcie jednostronne i wład-

${ }^{11}$ Odmiennie: J. Szachułowicz, Zmiany w ustawie o ubezpieczeniu społecznym rolników indywidualnych, ,Palestra” 1990, nr 4-5, s. 27.

12 M. Szewczyk, Glosa do wyroku NSA z dnia 13 marca 1990 r., II SA 77/90, „Samorząd Terytorialny” 1992, nr 1-2, s. 104-106; idem, Nieodplatne nabycie działek na podstawie przepisów emerytalno-rentowych, „Samorząd Terytorialny” 1993, nr 7-8, s. 80-84.

${ }_{13}$ Dz. U. Nr 32, poz. 191 ze zm.

${ }^{14}$ M. Szewczyk, Nabycie własności działki gruntu pod budynkami wyłaczonymi od przekazania na własność państwa przed 1 stycznia 1983 r., „Nowe Prawo” 1990, nr 10-12, s. 18; także uzasadnienie uchwały NSA z 5 marca 2001 r., sygn. akt: OPK 24/00, ONSA 2001, nr 3, poz. 106. 
cze, nie powinna zastępować umownych form obrotu nieruchomościami, zwłaszcza prywatnymi.

Analizowany przepis art. 6 u.z.u.s.r. jest niewątpliwie wyrazem procesów uwłaszczeniowych. Wobec tego trzeba uznać, że odnosi się on tylko do przypadków, gdy grunt pod budynkiem stanowi własność Skarbu Państwa albo jednostki samorządu terytorialnego. Przy czym Skarb Państwa, gmina, powiat lub samorząd województwa muszą być jedynymi właścicielami gruntu pod budynkiem. Nie jest dopuszczalna realizacja roszczenia o nieodpłatne nabycie działki siedliskowej w przypadku, gdy Skarb Państwa, gmina, powiat lub samorząd województwa mają tylko udział w prawie własności gruntu (działki siedliskowej). W trybie art. 6 u.z.u.s.r. nie można dokonać zwrotu ułamkowo wyrażonego udziału w nieruchomości gruntowej ${ }^{15}$. Inaczej mówiąc, przedmiotem uwłaszczenia, unormowanego w art. 6 u.z.u.s.r., nie może być udział we współwłasności danej nieruchomości gruntowej, gdy nieruchomość jest współwłasnością Skarbu Państwa (gminy) i osób trzecich ${ }^{16}$.

Warto podkreślić, że zgodnie z art. 6 u.z.u.s.r. właścicielom budynków znajdujących się na działce gruntu, która wchodziła w skład gospodarstwa rolnego przekazanego państwu przed 1 stycznia 1983 r., przysługuje nieodpłatnie na własność działka gruntu, na której te budynki zostały wzniesione. Nie chodzi o całą dotychczasową działkę w znaczeniu geodezyjnym, lecz o wyodrębnienie nowej działki o wielkości i cechach geometrycznych odpowiednich dla istniejącego budynku (budynków). Współcześnie taką działkę nazywamy działką budowlaną ${ }^{17}$. Działka budowlana musi umożliwiać prawidłowe i racjonalne korzystanie $\mathrm{z}$ budynku.

Konieczną cechą działki budowlanej jest dostęp do drogi publicznej. Dlatego w art. 6 zd. 2 u.z.u.s.r. postanowiono, że z własnością wyłączonej nieruchomości powinna być związana służebność gruntowa w zakresie niezbędnym do korzystania z niej. Niewątpliwie chodzi o służebność drogi koniecznej. Zgodnie z art. 145 § 2 k.c., przeprowadzenie drogi koniecznej nastąpi z uwzględnieniem potrzeb nieruchomości niemającej dostępu do

${ }^{15}$ E. Klat-Górska, Nieodplatnie nabycie prawa własności działki gruntu na podstawie art. 6 ustawy z 24.02.1989 r. o zmianie ustawy o ubezpieczeniu społecznym rolników indywidualnych i ich rodzin oraz o zmianie ustawy o podatku rolnym. Glosa do wyroku NSA z dnia 23 października 2015 r., I OSK 127/14, „Orzecznictwo w Sprawach Samorządowych” 2016, nr 2, s. 129-137.

${ }^{16}$ Wyrok WSA w Białymstoku z 17 stycznia 2017 r., sygn. akt: II SA/Bk 786/16, Lex nr 2197574.

${ }^{17}$ Definicja działki budowlanej została zamieszczona w dwóch przepisach: art. 2 pkt 12 ustawy z 27 marca 2003 r. o planowaniu i zagospodarowaniu przestrzennym (tekst jedn. Dz. U. z 2020 r., poz. 293 ze zm.); art. 4 pkt 3a ustawy z 21 sierpnia 1997 r. o gospodarce nieruchomościami (tekst jedn. Dz. U. z 2020 r., poz. 65 ze zm.). 
drogi publicznej oraz z najmniejszym obciążeniem gruntów, przez które droga ma prowadzić.

W świetle powyższych uwag należy uznać, że właściciel budynku ma roszczenie o nieodpłatne nabycie własności działki niezbędnej do prawidłowego i racjonalnego korzystania z budynku, a także służebności gruntowej niezbędnej do korzystania z budynku i działki.

W myśl art. 6 zd. 3 u.z.u.s.r. o przeniesieniu własności działki, jej wielkości oraz o ustanowieniu służebności orzeka terenowy organ administracji państwowej o właściwości szczególnej stopnia podstawowego. roszczenie właściciela budynku jest więc realizowane w drodze decyzji administracyjnej.

W wyniku reformy ustrojowej przeprowadzonej w 1990 r. nastąpiła zmiana właściwości organów. Zgodnie z art. 5 pkt 22 ustawy z 17 maja 1990 r. o podziale zadań i kompetencji określonych w ustawach szczególnych pomiędzy organy gminy a organy administracji rządowej oraz o zmianie niektórych ustaw ${ }^{18}$ orzekanie o przeniesieniu własności działki, jej wielkości oraz o ustanowieniu służebności gruntowej pod budynkami na rzecz właściciela tych budynków przeszło do właściwości rejonowych organów rządowej administracji ogólnej, czyli kierowników urzędów rejonowych ${ }^{19}$. Organ ten był właściwy bez względu na okoliczność, czy dana nieruchomość była własnością Skarbu Państwa, czy gminy ${ }^{20}$.

$\mathrm{W}$ rezultacie zmian $\mathrm{w}$ podstawowym podziale terytorialnym kraju oraz zmian struktur administracji publicznej od 29 października 1998 r. określone w przepisach zadania urzędów rejonowych rządowej administracji ogólnej oraz zadania i kompetencje kierowników tych urzędów przeszły do właściwości starosty jako zadania z zakresu administracji rządowej ${ }^{21}$. Tym samym organem właściwym do wydawania decyzji na podstawie art. 6 zd. 3 u.z.u.s.r. został starosta.

3. Rolnik, który przekazał gospodarstwo rolne państwu w zamian za świadczenie emerytalno-rentowe, jeśli nie zatrzymał budynku (budynków) na własność, mógł skorzystać z uprawnienia do bezpłatnego korzystania z lokalu. Niezależnie od tego, czy rolnik zachował własność budynku, czy też tylko możliwość korzystania z niezbędnego lokalu, zawsze mógł wnioskować o prawo do użytkowania tzw. działki przydomowej.

${ }_{18}$ Dz. U. Nr 34, poz. 198 ze zm.

19 Art. 36 i nast. ustawy z 22 marca 1990 r. o terenowych organach rządowej administracji ogólnej (tekst jedn. Dz. U. z 1998 r., Nr 32, poz. 176 ze zm.).

${ }^{20}$ Uchwała NSA w składzie 5 sędziów z 5 marca 2001 r., sygn. akt: OPK 24/00, Lex nr 47758.

${ }^{21}$ Art. 94 ustawy z 13 października 1998 r. Przepisy wprowadzające ustawy reformujące administrację publiczną (Dz. U. Nr 133, poz. 872 ze zm.). 
Zgodnie z art. 7 ust. 1 zd. 2 w zw. z art. 1 ust. 2 ustawy z 28 czerwca 1962 r. o przejmowaniu niektórych nieruchomości rolnych w zagospodarowanie lub na własność państwa oraz o zaopatrzeniu emerytalnym właścicieli tych nieruchomości i ich rodzin ${ }^{22}$ właściciel nieruchomości, który wyłączył z przekazanego państwu gospodarstwa rolnego budynki mieszkalne i gospodarskie w celu zaspokojenia potrzeb swoich i zamieszkałej z nim rodziny, mógł dodatkowo zachować działkę gruntu o powierzchni do 0,2 ha. Ponadto $\mathrm{w}$ razie przejęcia w zagospodarowanie całej nieruchomości rolnej wraz z budynkami właściciel nieruchomości zachowywał prawo do dalszego nieodpłatnego zajmowania lokalu mieszkalnego i pomieszczeń gospodarskich w rozmiarze niezbędnym do zaspokojenia potrzeb jego i zamieszkałej z nim rodziny, a także prawo do użytkowania działki gruntu o powierzchni do 0,2 ha. Jeżeli jednak przejęcie całości budynków znajdujących się na nieruchomości było potrzebne do należytego zagospodarowania nieruchomości, to właścicielowi nieruchomości przydzielano nieodpłatnie odpowiedni zastępczy lokal mieszkalny, pomieszczenia gospodarskie i działkę gruntu o powierzchni do 0,2 ha (art. 2 ust. 1 ustawy).

W myśl art. 4 ust. 3 pkt 1 ustawy z 24 stycznia 1968 r. o rentach i innych świadczeniach dla rolników przekazujących nieruchomości rolne na własność państwa w przypadku, gdy budynki wchodzące w skład przejmowanych nieruchomości były potrzebne do należytego zagospodarowania tych nieruchomości, państwo za zgodą rolnika mogło przejąć te budynki na własność. W zamian za to zapewniało rolnikowi bezpłatne dożywotnie użytkowanie lokalu mieszkalnego i pomieszczeń gospodarskich w przejętych lub innych budynkach w rozmiarze niezbędnym do zaspokojenia jego potrzeb.

Powyższe rozwiązania prawne były przenoszone do kolejnych ustaw regulujących materię rent i emerytur rolniczych. Zgodnie $\mathrm{z}$ art. 12 ust. 1 ustawy z 29 maja 1974 r. o przekazywaniu gospodarstw rolnych na własność państwa za rentę i spłaty pieniężne na wniosek rolnika, który przekazał gospodarstwo rolne za rentę, przydzielano do bezpłatnego użytkowania działkę gruntu rolnego o powierzchni do 0,5 ha, a w razie przekazania budynków - również lokal mieszkalny i pomieszczenia gospodarskie w rozmiarze niezbędnym do zaspokojenia potrzeb rolnika i jego rodziny. Jeżeli prawo do renty za gospodarstwo rolne służyło obojgu małżonkom, to wskazane uprawnienia przysługiwały im łącznie (art. 12 ust. 2 ustawy). Jeżeli prawo do renty służyło współwłaścicielom niebędącym małżonkami, to omawiane uprawnienia przysługiwały współwłaścicielom, dla których praca w przekazanym gospodarstwie stanowiła główne źródło utrzymania (art. 12 ust. 3 ustawy).

\footnotetext{
${ }^{22}$ Dz. U. Nr 38, poz. 166 ze zm.
} 
W myśl art. 55 ust. 2 ustawy z 27 października 1977 r. o zaopatrzeniu emerytalnym oraz innych świadczeniach dla rolników i ich rodzin właścicielowi, który przekazał państwu nieruchomości wraz z budynkami, przysługiwało prawo do bezpłatnego: 1) korzystania z lokalu mieszkalnego i pomieszczeń gospodarskich $\mathrm{w}$ rozmiarze niezbędnym do zaspokojenia jego potrzeb; 2) użytkowania działki gruntu o powierzchni do 0,3 ha. Zgodnie $\mathrm{z}$ art. 57 cyt. ustawy ustalenie określonych wyżej uprawnień właściciela następowało w formie decyzji naczelnika gminy.

Po raz ostatni omawiana materia była normowana w ustawie z 14 grudnia 1982 r. o ubezpieczeniu społecznym rolników indywidualnych i członków ich rodzin, która obowiązywała do 1 stycznia 1991 r. Zgodnie z art. 56 ust. 1 tej ustawy rolnik, który przekazał gospodarstwo rolne następcy lub państwu wraz z budynkami, uzyskiwał prawo do bezpłatnego korzystania z lokalu mieszkalnego i pomieszczeń gospodarskich w zakresie niezbędnym do zaspokajania swoich potrzeb i potrzeb członków rodziny. Ponadto rolnik, który przekazał gospodarstwo rolne następcy lub państwu, miał prawo do użytkowania działki gruntu rolnego o powierzchni nieprzekraczającej 10\% obszaru przekazanego gospodarstwa, nie więcej jednak niż o powierzchni 0,3 ha (art. 56 ust. 2 ustawy). Jeżeli prawo do emerytury lub renty przysługiwało obojgu małżonkom, to powyższe uprawnienia przysługiwały im łącznie.

W świetle przywołanych regulacji prawnych działka gruntu pozostawiona do dyspozycji rolnika była niewielka, a jej powierzchnia nie mogła przekraczać 0,2 ha, później 0,5 ha, a w ostatnim okresie 0,3 ha. Była to zatem działka o charakterze ogrodu przydomowego i służyła zaspokajaniu potrzeb rolnika i jego rodziny. Przywołane wyżej regulacje prawne nie wskazują, aby działka przydomowa musiała zostać wydzielona geodezyjnie - w grę wchodził raczej podział quoad usum.

Warto zauważyć, że osoba, która przekazała gospodarstwo rolne państwu, otrzymywała prawo do użytkowania działki gruntu. Chodziło o możliwość bezpłatnego faktycznego korzystania z gruntu na własne potrzeby. Nie było to ograniczone prawo rzeczowe, jakim jest prawo użytkowania (art. 252-270 k.c.).

Ustawodawca uregulował los prawny działek przydomowych przyznanych do użytkowania przed 1 stycznia $1991 \mathrm{r}$. Zgodnie z art. 118 ust. 1 ustawy z 20 grudnia 1990 r. o ubezpieczeniu społecznym rolników ${ }^{23}$ osobie, której przysługuje prawo użytkowania działki gruntu z tytułu przekazania gospodarstwa rolnego państwu, w myśl dotychczasowych przepisów na jej wniosek przyznaje się nieodpłatnie własność tej działki. Z wnioskiem o przyznanie prawa własności działki przydomowej może wystąpić również

${ }^{23}$ Tekst jedn. Dz.U. z 2020 r., poz. 174 ze zm. [dalej: u.u.s.r.]. 
zstępny osoby uprawnionej, który po jej śmierci faktycznie włada, w zakresie odpowiadającym jej uprawnieniom, daną nieruchomością. Jeżeli jednak uprawnionymi są oboje małżonkowie, wniosek taki może być zgłoszony dopiero po śmierci ich obojga (art. 118 ust. 2a u.u.s.r.).

Należy zauważyć, że art. 118 ust. 1 u.u.s.r. dotyczy osób, którym przysługuje prawo użytkowania działki gruntu $\mathrm{z}$ tytułu przekazania gospodarstwa rolnego państwu. Jednak rolnicy przekazujący państwu gospodarstwo rolne za świadczenie emerytalno-rentowe nie otrzymywali prawa użytkowania, a jedynie prawo do użytkowania działki przydomowej. Nie było to zatem ograniczone prawo rzeczowe, lecz uprawnienie o charakterze alimentacyjnym do korzystania $\mathrm{z}$ działki gruntu w ramach gospodarstwa domowego. Mimo wskazanej nieścisłości terminologicznej nie ma wątpliwości, że art. 118 ust. 1 u.u.s.r. reguluje uwłaszczenie działek przydomowych.

Uprawnienie do bezpłatnego nabycia prawa własności działki przydomowej służy także zstępnym osoby, która przekazała gospodarstwo rolne państwu. Zstępny musi wykazać, że po śmierci osoby uprawnionej (i jej małżonka) faktycznie włada działką przydomową w tym samym zakresie, co jego zmarły wstępny. W orzecznictwie sądowym przeważa stanowisko, że faktyczne władanie działką oznacza konieczność osobistego i ciągłego korzystania $\mathrm{z}$ działki ${ }^{24}$. Jeżeli zstępny osoby uprawnionej doprowadził do ugorowania działki przydomowej albo oddał działkę innej osobie do prowadzenia upraw i pobierania pożytków, to traci roszczenie o bezpłatne nabycie działki w trybie art. 118 ust. 1 u.u.s.r.

Rolnik, który w zamian za świadczenie emerytalno-rentowe przekazał państwu gospodarstwo rolne wraz ze wszystkimi budynkami, zachowywał jednak prawo do dalszego nieodpłatnego zajmowania lokalu mieszkalnego i pomieszczeń gospodarskich w rozmiarze niezbędnym do zaspokojenia potrzeb jego i zamieszkałej z nim rodziny. Wymóg zabezpieczenia socjalnego był tak silny, że jeśli rolnik nie mógł z przyczyn obiektywnych pozostać w budynkach przejętych przez państwo, to należało mu wskazać inny budynek. Budynek zastępczy powinien składać się z lokalu mieszkalnego i pomieszczeń gospodarskich w rozmiarze niezbędnym do zaspokojenia potrzeb rolnika $\mathrm{i}$ jego rodziny.

${ }^{24}$ Wyrok WSA w Gdańsku z 18 września 2019 r., sygn. akt: II SA/Gd 153/19, Lex nr 2723165; wyrok WSA w Białymstoku z 12 kwietnia 2018 r., sygn. akt: II SA/Bk 92/18, Lex nr 2497133; wyrok WSA w Szczecinie z 22 lutego 2018 r., sygn. akt: II SA/Sz 110/18, Lex nr 2454424; wyrok NSA z 27 listopada 2012 r., sygn. akt: II OSK 1339/11, Lex nr 1971164; wyrok NSA z 29 września 2010 r., sygn. akt: I OSK 1609/09, Lex nr 745100; wyrok NSA z 20 stycznia 2003 r., sygn. akt: II SA 397/01, Lex nr 126748; wyrok NSA z 9 lipca 1998 r., sygn. akt: SA/Bk 1482/97, ONSA 1999, nr 2, poz. 62. 
Zgodnie $\mathrm{z}$ art. 118 ust. 2 u.u.s.r. osobie, której przysługuje prawo do bezpłatnego korzystania z lokalu mieszkalnego i pomieszczeń gospodarskich z tytułu przekazania gospodarstwa rolnego państwu, w myśl dotychczasowych przepisów (a więc obowiązujących przed 1 stycznia 1991 r.) na jej wniosek przyznaje się nieodpłatnie własność działki obejmującej budynki, w których znajdują się ten lokal i te pomieszczenia, o powierzchni niezbędnej do korzystania z tych budynków.

Należy zauważyć, że przywołana regulacja odnosi się do osób legitymujących się prawem do bezpłatnego korzystania z lokalu i pomieszczeń. Tymczasem przepisy o przejmowaniu gospodarstw rolnych przez państwo za świadczenia emerytalno-rentowe zmieniały się w czasie, co miało też wpływ na sposób określania uprawnień do lokalu i pomieszczeń. Początkowo było to prawo do dalszego nieodpłatnego zajmowania lokalu mieszkalnego i pomieszczeń gospodarskich (ustawa z 28 czerwca 1962 r.). Potem przyznano rolnikowi bezpłatne użytkowanie lokalu mieszkalnego i pomieszczeń gospodarskich (ustawa z 24 stycznia 1968 r. oraz ustawa z 29 maja 1974 r.). Dopiero w późniejszych regulacjach pojawia się prawo do bezpłatnego korzystania z lokalu mieszkalnego i pomieszczeń gospodarskich w rozmiarze niezbędnym do zaspokojenia potrzeb rolnika i członków jego rodziny (ustawa z 27 października 1977 r. oraz ustawa z 14 grudnia 1982 r.).

Niezależnie od przyjętej terminologii chodziło o szczególne uprawnienie, o dwóch niezmiennych cechach: po pierwsze, było to uprawnienie bezpłatne; po drugie, dotyczyło dysponowania lokalem mieszkalnym i pomieszczeniami gospodarskimi w rozmiarze niezbędnym do zaspokojenia potrzeb rolnika i zamieszkałej z nim rodziny. Treść uprawnienia wyznaczał zatem zakres potrzeb. Niewątpliwie było to uprawnienie wyraźnie motywowane względami socjalnymi i alimentacyjnymi.

W myśl art. 118 ust. 2a u.u.s.r. z wnioskiem o przyznanie prawa własności działki niezbędnej do korzystania z budynków może wystąpić również zstępny osoby uprawnionej, który po śmierci tej osoby faktycznie włada, w zakresie odpowiadającym jej uprawnieniom, daną nieruchomością, na której znajduje się lokal mieszkalny i pomieszczenia gospodarskie.

Należy zauważyć, że przedmiotem uwłaszczenia jest nieruchomość rozumiana jako grunt z budynkami, a nie nieruchomość lokalowa, czyli samodzielny lokal mieszkalny wraz z pomieszczeniami gospodarskimi. Zatem mimo że analizowana regulacja adresowana jest do osób, którym przysługuje prawo do bezpłatnego korzystania z lokalu mieszkalnego i pomieszczeń gospodarskich, to od osób tych wymaga się, aby faktycznie władały całą nieruchomością. Uwłaszczenie polega na wydzieleniu działki gruntu niezbędnej do korzystania z budynku mieszkalnego oraz budynku (budynków), 
w którym znajdują się pomieszczenia gospodarskie. Chodzi więc o działkę o znacznej powierzchni i granicach obejmujących przynajmniej dwa budynki.

Regulacja zamieszczona w art. 118 u.u.s.r. nie daje podstawy do ubiegania się o przyznanie własności nieruchomości w częściach ułamkowych ${ }^{25}$. Wobec tego wnioskodawca musi wykazać, że faktycznie włada całą działką przydomową, a także działką obejmującą budynki, w których znajdują się lokal mieszkalny i pomieszczenia gospodarskie.

Unormowania $\mathrm{z}$ art. 118 u.u.s.r. nie stosuje się, jeżeli działka nie jest przedmiotem własności Skarbu Państwa lub jednostki samorządu terytorialnego albo jeżeli przyznanie własności naruszałoby prawa osób trzecich do działki lub budynków, o których mowa w analizowanych przepisach (art. 118 ust. 3 u.u.s.r.).

Decyzje w sprawach nieodpłatnego nadania własności działki przydomowej oraz własności działki zabudowanej wydaje starosta na wniosek osoby uprawnionej (art. 118 ust. 4 u.u.s.r.).

4. Przedstawione wyżej przypadki nieodpłatnego nadania na własność działek gruntu wchodzących niegdyś w skład gospodarstwa rolnego przekazanego państwu można określić ogólnie jako uwłaszczenie. Chociaż uwłaszczenie nie jest pojęciem normatywnym, to tradycyjnie służy jako zbiorcze określenie nabycia praw do nieruchomości, które znajdują się w zasobach Skarbu Państwa lub jednostek samorządu terytorialnego. Uwłaszczenie można w jakiejś mierze uznać za przejaw tendencji prywatyzacyjnych. Na ogół odnosi się ono do w miarę jednorodnej grupy podmiotów, ale może mieć też wymiar powszechny i służyć wyposażeniu szerokich grup społecznych w określoną część majątku narodowego.

Ponieważ mamy do czynienia z określeniem pochodzącym z języka powszechnego, obejmuje ono dość różne przypadki. Uwłaszczenie polega zarówno na nabyciu przez określone podmioty tytułu prawnorzeczowego do nieruchomości pozostającej dotychczas tylko w posiadaniu, jak i na przekształceniu „słabszego” prawa do nieruchomości w prawo „silniejsze”. Najczęściej występują przypadki przekształcenia praw obligacyjnych, takich jak dzierżawa lub najem, w prawa rzeczowe do nieruchomości, takie jak użytkowanie, użytkowanie wieczyste, własność.

Proces uwłaszczenia zachodzi na pograniczu regulacji prawa publicznego i prawa prywatnego. Istotne znaczenie mają instrumenty władcze i jednostronne. Na przykładzie regulacji zamieszczonej w art. 6 u.z.u.s.r.

${ }^{25}$ C. Kociński, Postępowanie w sprawie nieodptatnego nadania na własność działki będacej $w$ dożywotnim użytkowaniu osoby fizycznej, w trybie art. 118 ustawy o ubezpieczeniu społecznym rolników, „Nowe Zeszyty Samorządowe. Opinie Prawne” 2010, nr 5, poz. 81. 
i art. 118 u.u.s.r. widoczna jest rola organów administracji publicznej, które swoje zadania wykonują w drodze decyzji administracyjnej. Nawet terminologia stosowana przez ustawodawcę wskazuje, że mamy do czynienia z przypadkami nadania lub przekazania działki gruntu, a nie z procedurą nabycia.

Na progu lat 90. XX wieku ustawodawca otworzył drogę do uwłaszczenia państwowych i komunalnych osób prawnych na gruntach Skarbu Państwa i gmin, a także osób fizycznych, które wybudowały garaż z własnych środków na gruntach Skarbu Państwa i gmin ${ }^{26}$. Stopniowo wprowadzona została możliwość sprzedaży domów, lokali mieszkalnych i budynków gospodarczych ich najemcom wraz z niezbędnymi gruntami, wchodzących w skład Zasobu Własności Rolnej Skarbu Państwa ${ }^{27}$. Ustawodawca zapewnił szerokie możliwości nabywania nieruchomości zabudowanych budynkami mieszkalnymi i samodzielnych lokali mieszkalnych nieprzydatnych Lasom Państwowym. Pierwszeństwo nabycia lokali mają pracownicy i byli pracownicy Lasów Państwowych, a także osoby bliskie, pozostałe po pracownikach, które w dniu ich śmierci zamieszkiwały razem $\mathrm{z}$ nimi ${ }^{28}$. Uregulowana została także możliwość zbywania mieszkań zakładowych i domów jednorodzinnych poprzez przyznanie najemcom takich mieszkań pierwszeństwa nabycia ${ }^{29}$. Pierwszeństwo przysługuje pracownikom i byłym pracownikom, a po ich śmierci - współmałżonkowi, dzieciom i innym osobom, które stale zamieszkiwały z najemcą w lokalu do chwili jego śmierci.

Przedstawione wyżej uregulowania odnoszące się do uwłaszczenia zasobów mieszkaniowych należących przed 1990 r. do mienia ogólnonarodowego ujawniają wyraźną odrębność rozwiązań ustawowych w zakresie losów prawnych domów, budynków, lokali mieszkalnych i pomieszczeń gospodarskich, które pozostawiono do korzystania rolnikom i ich rodzinom po przekazaniu gospodarstwa rolnego państwu. W świetle regulacji zamieszczonej w art. 6 u.z.u.s.r. i art. 118 u.u.s.r. rolnicy, a także ich następcy prawni lub faktyczni mają roszczenie o nieodpłatne nabycie działki gruntu wraz z budynkiem. Roszczenie to jest realizowane w trybie postępowania

${ }^{26}$ Art. 2-2a, art. 8 ustawy z 29 września 1990 r. o zmianie ustawy o gospodarce gruntami i wywłaszczaniu nieruchomości (Dz. U. Nr 79, poz. 464 ze zm.).

${ }^{27}$ Art. 42, 46, 46a ustawy z 19 października 1991 r. o gospodarowaniu nieruchomościami rolnymi Skarbu Państwa (tekst jedn. Dz. U. z 2020 r., poz. 396 ze zm.).

${ }^{28}$ Art. 40a ustawy z 28 września 1991 r. o lasach (tekst jedn. Dz. U. z 2020 r., poz. 6 ze zm.).

${ }^{29}$ Ustawa z 15 grudnia 2000 r. o zasadach zbywania mieszkań będących własnością przedsiębiorstw państwowych, niektórych spółek handlowych z udziałem Skarbu Państwa, państwowych osób prawnych oraz niektórych mieszkań będących własnością Skarbu Państwa (tekst jedn. Dz. U. z 2016 r., poz. 52 ze zm.); art. 41 i nast. ustawy z 8 września 2000 r. o komercjalizacji i restrukturyzacji przedsiębiorstwa państwowego „Polskie Koleje Państwowe” (tekst jedn. Dz. U. z 2020 r., poz. 292 ze zm.). 
administracyjnego i załatwiane w drodze decyzji właściwego organu administracji publicznej.

W przypadku mieszkań i domów jednorodzinnych należących do Zasobu Własności Rolnej Skarbu Państwa, Lasów Państwowych, a także pozostałych po zlikwidowanych lub skomercjalizowanych przedsiębiorstwach państwowych możliwość ich nabycia na własność przez dotychczasowych najemców powstaje dopiero $\mathrm{z}$ chwilą podjęcia przez właściciela zamiaru przeznaczenia nieruchomości do sprzedaży. Pozycja najemców jest o tyle uprzywilejowana, że służy im pierwszeństwo nabycia nieruchomości oraz są uprawnieni do otrzymania bonifikaty od ceny sprzedaży. Sama sprzedaż następuje $\mathrm{w}$ drodze zawarcia umowy notarialnej.

Budynki, lokale i pomieszczenia oraz działka przydomowa, wymienione $\mathrm{w}$ art. 6 u.z.u.s.r. i art. 118 u.u.s.r., zostały wyodrębnione z całości gospodarstwa rolnego przekazanego państwu w zamian za świadczenie emerytalno-rentowe, w celu zaspokojenia potrzeb mieszkaniowych rolnika i mieszkających z nim członków rodziny. Pomieszczenia gospodarskie i działka przydomowa (ogród) były ściśle powiązane z potrzebami mieszkaniowymi rolnika i jego rodziny z uwagi na sposób życia na polskiej wsi w latach 70. i 80. XX wieku.

Po upływie 30 lat obowiązywania omawianych przepisów konieczna jest refleksja nad tym, czy przepisy te spełniają oczekiwaną funkcję ochronną i organizacyjną. Funkcja ochronna zmierza do ochrony wartości społecznych. Należy podkreślić, że stosowanie przepisów art. 6 u.z.u.s.r. i art. 118 u.u.s.r. jest utrudnione przez wciąż niewygaszone spory interpretacyjne. Ponadto art. 6 u.z.u.s.r. nie został poddany jakimkolwiek zmianom, które uwzględniałyby aktualny stan zadań i organizacji administracji publicznej.

Duże zastrzeżenia budzi metoda administracyjnoprawna rozwiązywania kwestii własnościowych związanych ze skutkami przekazywania przez rolników gospodarstw rolnych na rzecz państwa w zamian za świadczenie emerytalno-rentowe. Regulowanie spraw własnościowych za pomocą decyzji administracyjnej powoduje, że dotychczasowi właściciele gruntu, czyli Skarb Państwa i jednostki samorządu terytorialnego, zostają pozbawieni ochrony prawnej. Legitymacja strony postępowania administracyjnego będzie przysługiwać tylko wnioskodawcy, czyli właścicielowi budynku, lub osobom uprawnionym do korzystania z lokalu mieszkalnego, pomieszczeń gospodarskich i działki przydomowej.

Zastrzeżenia budzi także to, że przepisy art. 6 u.z.u.s.r. i art. 118 u.u.s.r. tworzą podstawę do nieodpłatnego uwłaszczenia, czyli z uszczerbkiem dla dotychczasowego właściciela. Trudno o uzasadnienie takiego rozwiązania, zwłaszcza w przypadkach wskazanych w art. 118 u.u.s.r. Przepis ten otwiera drogę do 
darmowego uwłaszczenia osób, które od co najmniej 30 lat miały prawo do bezpłatnego korzystania z lokalu mieszkalnego i pomieszczeń gospodarskich z tytułu przekazania gospodarstwa rolnego państwu. Należy sądzić, że osoby takie nie tylko nie ponosiły opłat na rzecz właściciela, ale także nie partycypowały w remontach i nakładach ponoszonych przez właściciela w celu utrzymania nieruchomości w niepogorszonym stanie.

Wydaje się, że sytuacja prawna osób, którym przysługuje prawo do bezpłatnego korzystania z lokalu mieszkalnego i pomieszczeń gospodarskich wraz z działką przydomową, powinna być zrównana z pozycją, jaką mają najemcy lokali mieszkalnych i domów jednorodzinnych - byli pracownicy państwowych gospodarstw rolnych, Lasów Państwowych czy przedsiębiorstw państwowych. Dlatego zamiast roszczenia realizowanego na drodze administracyjnej adresaci norm prawnych zawartych w art. 6 u.z.u.s.r. i art. 118 u.u.s.r. powinni zostać wyposażeni w ustawowe pierwszeństwo w nabyciu nieruchomości. Z pierwszeństwa można skorzystać, gdy właściciel gruntu przeznaczy go do sprzedaży. Ogólna procedura realizacji pierwszeństwa została uregulowana w art. 35 ustawy z 21 sierpnia $1997 \mathrm{r}$. o gospodarce nieruchomościami. Ustawodawca może także odwołać się do rozwiązań w zakresie realizacji pierwszeństwa przyjętych w ustawie z 19 października 1991 r. o gospodarowaniu nieruchomościami rolnymi Skarbu Państwa.

Omawiany art. 118 u.u.s.r. mógłby otrzymać następujące brzmienie:

„1. Osobie, której przysługuje prawo użytkowania działki gruntu z tytułu przekazania gospodarstwa rolnego państwu w myśl dotychczasowych przepisów, służy pierwszeństwo nabycia prawa własności tej działki.

2. Osobie, której przysługuje prawo do bezpłatnego korzystania z lokalu mieszkalnego i pomieszczeń gospodarskich z tytułu przekazania gospodarstwa rolnego państwu w myśl dotychczasowych przepisów, służy pierwszeństwo nabycia prawa własności działki obejmującej budynki, w których znajdują się ten lokal i te pomieszczenia, o powierzchni niezbędnej do korzystania z tych budynków.

3. Pierwszeństwo nabycia prawa własności działki określonej w ust. 1 lub 2 przysługuje także zstępnemu osoby uprawnionej, o której mowa w tych przepisach, który po śmierci tej osoby faktycznie włada, w zakresie odpowiadającym jej uprawnieniom, daną nieruchomością; jeżeli jednak uprawnionymi są oboje małżonkowie, pierwszeństwo staje się aktualne dopiero po śmierci ich obojga.

4. Przepisów ust. 1-3 nie stosuje się, jeżeli działka nie jest przedmiotem własności Skarbu Państwa lub jednostki samorządu terytorialnego. 
5. Do wykonania pierwszeństwa stosuje się odpowiednio przepisy ustawy z 19 października 1991 r. o gospodarowaniu nieruchomościami rolnymi Skarbu Państwa".

Oddzielnego uregulowania wymaga kwestia ceny sprzedaży. Cena zaproponowana przez właściciela $\mathrm{w}$ ofercie sprzedaży będzie ceną odpowiadającą wartości rynkowej nieruchomości. Niemniej ustawodawca powinien przyznać osobie uprawnionej do pierwszeństwa w nabyciu określoną bonifikatę. W przypadku gruntów stanowiących własność jednostek samorządu terytorialnego o wysokości bonifikaty będą decydowały organy stanowiące tych jednostek. Wysokość bonifikaty może zostać powiązana z rozliczeniem nakładów na nieruchomość, poczynionych przez osobę uprawnioną do pierwszeństwa w nabyciu.

Odmiennie przedstawia się kwestia roszczeń, o których mowa w art. 6 u.z.u.s.r. Wskazany przepis nie realizuje funkcji ochronnej, lecz zmierza do prawidłowego ukształtowania instytucji własności nieruchomości. Zapewnienie, aby budynek dzielił los prawny gruntu, stanowi przejaw funkcji organizacyjnej przepisów prawa, która jest wyrazem dążenia do prawidłowego ukształtowania instytucji i struktur formalnych ${ }^{30}$.

Unormowanie zamieszczone $\mathrm{w}$ art. 6 u.z.u.s.r. adresowane jest do aktualnego właściciela budynków wyłączonych z gospodarstwa rolnego przekazanego państwu. Właścicielem może być także kolejny nabywca, który nie pozostaje w relacjach rodzinnych z rolnikiem, który otrzymał świadczenie emerytalno-rentowe i zarazem zachował budynek jako odrębną własność. Każdy właściciel budynku powinien być wyposażony w roszczenie o nabycie działki gruntu pod budynkiem (budynkami). Chodzi bowiem o przywrócenie zasady superficies solo cedit i zapewnienie wydzielonym działkom siedliskowym odpowiedniej obsługi komunikacyjnej z uwzględnieniem właściwego dostępu do drogi publicznej.

Roszczenie powinno przysługiwać także w przypadku, gdy grunt pod budynkiem stał się własnością prywatną. Przepis art. 6 uz.u.s.r. takiej sytuacji nie przewiduje. Niemniej wprowadzenie takiego rozwiązania jest konieczne ze względu na zasadę superficies solo cedit. Roszczenie właściciela budynku wobec właściciela gruntu byłoby realizowane poprzez zawarcie notarialnej umowy sprzedaży lub wytoczenie powództwa przed sądem powszechnym. Nabycie własności gruntu i ustanowienie odpowiedniej służebności następowałoby odpłatnie z uwzględnieniem wartości rynkowej nabywanych praw.

${ }^{30}$ Z. Ziembiński, w: S. Wronkowska, Z. Ziembiński, Zarys teorii prawa, Poznań 2001, s. $233 \mathrm{i} \mathrm{nn}$. 
Obecny zakres stosowania art. 6 u.z.u.s.r. jest ograniczony tylko do gruntów Skarbu Państwa oraz gruntów stanowiących własność jednostek samorządu terytorialnego. $Z$ tego względu przyjęto administracyjnoprawną drogę regulacji stosunków własnościowych. Rozszerzenie zakresu stosowania art. 6 u.z.u.s.r. wymagałoby odebrania organom administracji publicznej kompetencji do wydawania decyzji administracyjnej i otwarcia na stosunki umowne.

Ze względu na ochronę wartości społecznych oddzielnie należałoby uregulować przypadek, gdy grunt pod budynkiem (budynkami) nadal należy do zasobów publicznych, a odrębna własność budynku przysługuje rolnikowi, jego małżonkowi lub zstępnemu, jeśli zamieszkiwali z nim do chwili jego śmierci. Wówczas są uzasadnione podstawy do nieodpłatnego nabycia działki gruntu potrzebnej do korzystania z budynku (budynków).

W świetle powyższych uwag omawiany art. 6 u.z.u.s.r. mógłby otrzymać następujące brzmienie:

„1. Właścicielom budynków znajdujących się na działce gruntu, która wchodziła w skład gospodarstwa rolnego przekazanego państwu na podstawie przepisów obowiązujących przed dniem 1 stycznia 1983 r., przysługuje roszczenie o przeniesienie własności działki gruntu, na której te budynki zostały wzniesione.

2. Wraz z przeniesieniem własności działki ustanawiana jest służebność gruntowa w zakresie niezbędnym do korzystania z nieruchomości.

3. Jeżeli grunt, na którym budynki zostały wzniesione, stanowi własność Skarbu Państwa lub jednostki samorządu terytorialnego, a właścicielem budynków znajdujących się na działce gruntu jest rolnik, który przekazał gospodarstwo rolne państwu, jego współmałżonek lub zstępny, jeśli zamieszkiwali z nim do chwili jego śmierci, to własność działki gruntu przysługuje nieodpłatnie".

Zaproponowane odejście od regulacji omawianej problematyki w trybie administracyjnoprawnym harmonizuje $\mathrm{z}$ dostrzegalną tendencją do regulowania podobnych zdarzeń za pomocą metod właściwych prawu cywilnemu. Nie oznacza to pełnej rezygnacji z procedury administracyjnej. Przed sprzedażą działek gruntu, o których mowa w art. 6 u.z.u.s.r. i art. 118 u.u.s.r., należy dokonać ich geodezyjnego wydzielenia. Podział gruntu wymaga zatwierdzenia w drodze decyzji administracyjnej wydawanej przez wójta, burmistrza lub prezydenta miasta właściwego ze względu na położenie nieruchomości ${ }^{31}$. W przypadku polityki uwłaszczeniowej korzystanie z instrumentów władczych takich jak decyzja administracyjna powinno być ograniczone w czasie.

${ }^{31}$ Art. 94 i 96 ustawy z 21 sierpnia 1997 r. o gospodarce nieruchomościami. 
Regulacje pochodzące z początku lat 90 . XX wieku określały na ogół ustawowy termin, do którego osoby uprawnione mogły składać wnioski o wydanie decyzji uwłaszczeniowej. Później roszczenie wygasało z uwagi na to, że po okresie przejściowym powinna nastąpić stabilizacja stosunków własnościowych.

Podobnie jest $\mathrm{w}$ przypadku roszczeń uregulowanych $\mathrm{w}$ art. 6 u.z.u.s.r. i art. 118 u.u.s.r. Tutaj także konieczne jest zamknięcie okresu przejściowego i wprowadzenie zwykłych zasad gospodarowania nieruchomościami. Postulowana nowelizacja omawianych przepisów powinna prowadzić do ustabilizowania stosunków własnościowych na wsi według metod właściwych prawu cywilnemu.

\title{
PURCHASE OF PLOTS OF LAND \\ INCLUDED IN AN AGRICULTURAL HOLDING \\ TRANSFERRED TO THE STATE UNDER THE RETIREMENT AND DISABILITY PENSION REGULATIONS
}

\author{
Sum mary
}

The purpose of this article was to resolve problems related to the claims concerning the purchase of land on which the buildings which were once part of an agricultural holding transferred to the State for pension benefits. The solutions adopted by the legislator do not harmonise with the regulations governing the acquisition of land by other social groups. An administrative claim procedure and the absence of time limits for the filing of claims are a shortcoming. The right solution would be to give farmers and their successors statutory priority in the acquisition of land with buildings. Such priority should be implemented during the sale procedure.

\section{ACQUISTO DI APPEZZAMENTI DI TERRENO FACENTI PARTE DELL'AZIENDA AGRICOLA CEDUTA ALLO STATO SECONDO LA NORMATIVA PENSIONISTICA E DI INVALIDITÀ}

\section{Riassunto}

L'articolo si propone di discutere le problematiche in materia di rivendicazioni legate all'acquisto di terreni su cui si trovano i fabbricati che un tempo facevano parte di un'azienda agricola, poi ceduta allo Stato in cambio di prestazioni pensionistiche e di invalidità. Le soluzioni adottate dal legislatore non risultano essere in armonia con la normativa in materia di acquisto di immobili da parte di altri gruppi sociali. Ad essere difettosa è la soluzione di perseguire le rivendicazioni in modalità amministrativa, nonché la mancanza di scadenze per la presentazione delle stesse. Una soluzione adeguata sarebbe quella di concedere agli agricoltori e ai loro successori la priorità, stabilita dalla legge, nell'acquisire terreni con i fabbricati. Tale priorità dovrebbe essere esercitata durante la procedura di vendita. 